\title{
Effects of Sugar Beets on Steer Backgrounding Performance, Sheep Nutrient Metabolism, and Rumen Fermentation Characteristics
}

\author{
Ian R. McGregor \\ Dept. of Animal and Range Sciences, Montana State University \\ PO Box 172900, Bozeman, MT 59717-2900 \\ Tel: 1-541-883-7131 E-mail: ian.mcgregor@oregonstate.edu \\ Chad M. Page \\ Dept. of Animal and Range Sciences, Montana State University \\ PO Box 172900, Bozeman, MT 59717-2900
}

Tel: 1-602-615-5952 E-mail: cmpage18@gmail.com

\begin{abstract}
Whitney C. Stewart
Department of Animal Science, University of Wyoming 1000 East University Avenue, Laramie, WY 82071

Tel: 1-307-766-5374 Email: whit.stewart@uwyo.edu
\end{abstract}

Megan L. Van Emon (Corresponding Author)

Dept. of Animal and Range Sciences, Montana State University

PO Box 172900, Bozeman, MT 59717-2900

Tel: 1-406-874-8286 E-mail: megan.vanemon@montana.edu

Received: August 6, 2018 Accepted: August 20, 2018

doi:10.5296/jas.v6i3.13464 URL: https://doi.org/10.5296/jas.v6i3.13464 


\section{Abstract}

A performance and metabolism study were performed to evaluate the effects of sugar beets on steer backgrounding performance, sheep nutrient metabolism, and rumen fermentation characteristics. In both experiments, four dietary treatments were used where sugar beets replaced $0 \%(0 \mathrm{SB}), 15 \%(15 \mathrm{SB}), 30 \%(30 \mathrm{SB})$, or $45 \%(45 \mathrm{SB})$ of barley on a DM basis. Forty-eight Angus steers were used in a completely randomized design to conduct the $50 \mathrm{~d}$ performance study. Neither ADG nor G:F were effected $(P \geqslant 0.33)$ by treatment. In the metabolism study, a 4 x 4 replicated Latin Square design was used to observe the effects of increasing dietary inclusion of sugar beets on the nutrient metabolism and ruminal ferme ntation characteristics of eight growing wethers. A cubic effect $(P=0.04)$ was observed for nitrogen balance. Propionate concentration decreased linearly $(\mathrm{P}=0.05)$ with increasing sugar beets in the diet. The acetate to propionate ratio increased linearly $(P=0.03)$ with increasing sugar beets in the diet. Butyrate concentration demonstrated a treatment $\times$ time effect $(\mathrm{P}=0.01)$, where butyrate concentration increased with increasing sugar beets in the diet at 1300. Rumen $\mathrm{pH}$ exhibited a quadratic effect $(\mathrm{P}=0.05)$ at $1300 \mathrm{~h}$, with $15 \mathrm{SB}$ having the greatest $\mathrm{pH}$ and $45 \mathrm{SB}$ having the least $\mathrm{pH}$. Our results allow us to conclude that replacing barley with sugar beets up to $45 \%$ of the diet dry matter will have no deleterious effects on steer backgrounding performance or sheep nutrient metabolism, but may alter rumen fermentation patterns.

Keywords: steer; performance; sheep; nutrient metabolism; rumen characteristics; sugar beets

\section{Introduction}

Montana is a major producer of sugar beets in the Northern Great Plains (5th in the US; USDA, 2015a). During the 2014-2015 sugar beet harvest, approximately 20.5 million kilograms of sugar beets were not harvested (USDA, 2015b). Feedstock opportunities exist considering the energy content of sugar beets ( $81 \%$ total digestible nutrients; Lardy \& Schafer, 2008), as the non-harvested sugar beets could provide a readily available feedstuff for cattle and sheep producers that could potentially replace more traditional feedstuffs such as barley or corn. Minimal research has been conducted on the effects of feeding sugar beets to ruminant livestock. Sugar beets differ from traditional feedstuffs due to their moisture content (70-80\% moisture; Lardy \& Schafer, 2008) and how they store energy in the form of sugar rather than starch (12-20\% sugar; Agribusiness Handbook, 2009). In addition, sugar beets contain considerably less protein than barley and corn (barley $14.0 \%$ crude protein (CP), corn 9.8\% CP; NRC, 2000; sugar beets 6.8\% CP; Lardy \& Schafer, 2008).

Many studies have observed no negative effects on steer backgrounding performance or nutrient metabolism when sugar beets or sugar beet pulp replace more traditional energy sources (Huhtanen et al., 1988; Olfaz, Ocak, Erener, Cam, \& Garipoglu, 2005; Arrizon et al., 2012). In addition, other studies have observed many differences between the effects of sugar and starch on ruminal fermentation patterns (Vallimont et al., 2004; Ribeiro, Karnati, \& Eastridge, 2005). 


\section{Macrothink

Based on energy density, sugar beets may provide an excellent alternative to more traditional energy sources. Due to the chemical nature of sugar beets, we hypothesized that feeding increasing levels of sugar beets would have no deleterious effects on steer feedlot growth or sheep nutrient metabolism. Therefore, the objective of this study was to evaluate the effects of sugar beets on steer backgrounding performance and sheep nutrient metabolism.

\section{Materials and Methods}

All procedures were approved by the animal care and use committee of Montana State University (\#2015-AA09 \& \#2016-AA09).

\subsection{Backgrounding Trial}

\subsubsection{Animals and Diets}

Forty-eight Angus steers (260.7 \pm 3.4 kilograms; $\mathrm{kg}$ ) were used in a completely randomized design for a 50-day (d) study with animal as the experimental unit. Steers were weighed on consecutive days on $\mathrm{d}-1$ and 0 . Steers were stratified by body weight (BW) and assigned to 1 of 8 pens (6 steers per pen) equipped with GrowSafe (GrowSafe Systems Ltd., Airdrie, AB Canada) units to allow for individual feed intake measurement starting on $\mathrm{d} 0$. On $\mathrm{d} 0$, pens were allotted to one of the four dietary treatments $(n=12$ steers/treatment; 2 pens/treatment: Table 1): 1) 0SB: control diet with no sugar beets and 45\% barley; 2) 15SB: $15 \%$ sugar beets and 30\% barley; 3) 30SB: 30\% sugar beets and 15\% barley; and 4) 45SB: 45\% sugar beets and $0 \%$ barley. Sugar beets directly replaced rolled barley on a DM basis. All dietary treatments were formulated to meet or exceed the nutrient requirements of a 295-kg steer gaining $0.91 \mathrm{~kg} / \mathrm{d}$ (NRC, 2000). Steers had continuous access to water and shelter. Sugar beets were processed through a commercial wood chipper to reduce the particle size. Steers were weighed on consecutive days at the beginning of the trial (d -1 and 0), mid-point ( 26 and 27), and end (d 49 and 50) of the trial. Individual dry matter intake (DMI) and $\mathrm{kg}$ of gain per kg of DMI (G:F) of each steer was calculated. Two steers were removed from the study due to non-treatment related illness. Ration samples were collected weekly, composited by treatment by period, and dried in a forced-air drying oven at $60^{\circ} \mathrm{C}$ for 48 hours to determine dry matter (DM). 


\section{Macrothink}

Table 1. Ingredient and nutritional composition of diets fed to backgrounding steers (DM basis)

\begin{tabular}{|c|c|c|c|c|}
\hline \multirow[b]{2}{*}{ Item } & \multicolumn{4}{|c|}{ Dietary Treatment $^{1}$} \\
\hline & OSB & $15 \mathrm{SB}$ & $30 \mathrm{SB}$ & $45 \mathrm{SB}$ \\
\hline \multicolumn{5}{|l|}{ Ingredient, \% } \\
\hline Sugar beets ${ }^{2}$ & - & 15.0 & 30.0 & 45.0 \\
\hline Rolled barley & 45.0 & 30.0 & 15.0 & - \\
\hline Chopped hay & 45.0 & 41.0 & 36.9 & 32.75 \\
\hline Soybean meal & 6.25 & 10.40 & 14.75 & 19.0 \\
\hline Mineral premix ${ }^{3}$ & 0.90 & 0.90 & 0.90 & 0.90 \\
\hline Calcium carbonate & 1.25 & 1.10 & 0.85 & 0.75 \\
\hline Salt & 0.25 & 0.25 & 0.25 & 0.25 \\
\hline Deccox & 1.35 & 1.35 & 1.35 & 1.35 \\
\hline \multicolumn{5}{|c|}{ Nutritional Composition 4} \\
\hline $\mathrm{DM}, \%$ & 87.4 & 74.4 & 64.7 & 57.3 \\
\hline TDN, $\%$ & 66.6 & 65.5 & 64.5 & 63.4 \\
\hline $\mathrm{CP}, \%$ & 16.0 & 15.6 & 15.4 & 15.1 \\
\hline $\mathrm{Ca}: \mathrm{P}$ & 2.63 & 2.65 & 2.57 & 2.64 \\
\hline
\end{tabular}

${ }^{1}$ Dietary treatments were: 0SB: control diet with no added sugar beets; 15SB: 15\% sugar beets substituted for barley; 30SB: 30\% sugar beets substituted for barley; and 45SB: 45\% sugar beets substituted for barley on a DM basis.

${ }^{2}$ Sugar beets were processed through a wood chipper to reduce the particle size to reduce the risk of choking.

${ }^{3}$ Mineral premix: $13.6 \% \mathrm{Ca}, 10 \% \mathrm{P}, 15.6 \% \mathrm{NaCl}, 1.0 \% \mathrm{Mg}, 0.1 \% \mathrm{~K}$, 2,500 mg/kg Cu, $35 \mathrm{mg} / \mathrm{kg} \mathrm{Se,} \mathrm{8,500} \mathrm{mg/kg} \mathrm{Zn,} \mathrm{440,529} \mathrm{IU/kg} \mathrm{vitamin}$ A, 44,053 IU/kg vitamin D, and $881 \mathrm{IU} / \mathrm{kg}$ vitamin E.

${ }^{4}$ Calculated nutrient composition of the diets.

\subsubsection{Statistical Analysis}

The MIXED procedure of SAS was used for the statistical analysis of all performance data (SAS 9.4; SAS Inst. Inc., Cary, NC). Individual animal is the experimental unit. The dietary treatment was the fixed effect included in the model with a random effect of pen nested within treatment. Dry matter intake data was analyzed utilizing repeated measures with the fixed effects of dietary treatment, day, and the interaction. Four days of dry matter intake data were not calculated due to equipment failure. Pre-planned comparisons of linear, quadratic, and cubic contrasts were utilized to partition treatment effects. Significance was determined at $P \leq 0.05$, and tendencies were determined at $P \leq 0.10$. To partition day effects and treatment $\times$ day interactions, LS Means was utilized $(P \leq 0.05)$. 


\subsection{Metabolism Trial}

\subsubsection{Animals and Diets}

A $4 \times 4$ replicated Latin Square design was used to evaluate the effects of four diets varying in sugar beet concentration on the digestibility of DM, neutral detergent fiber (NDF), acid detergent fiber (ADF), Nitrogen $(\mathrm{N}), \mathrm{N}$ balance, as well as ruminal fermentation patterns of wethers. Wethers were weighed (average BW: $36.65 \mathrm{~kg}$ ) and allotted into one of four dietary treatments on $\mathrm{d} 0$ ( $\mathrm{n}=2$ wethers/treatment; 2 crates/treatment: Table 2): 1) 0SB: control diet with no sugar beets and 45\% barley; 2) 15SB: 15\% sugar beets and 30\% barley; 3) 30SB: $30 \%$ sugar beets and 15\% barley; and 4) 45SB: 45\% sugar beets and 0\% barley. All dietary treatments were formulated to meet or exceed the nutrient requirements of growing wethers (30 kg; NRC, 2007). Due to the protein content provided by sugar beets relative to barley, soybean meal was added to the total mixed ration (TMR) as sugar beet concentration increased in order to make the diets isonitrogenous. Water was added to each dietary treatment to equilibrate moisture content among treatments. Each experimental period was 20 $\mathrm{d}$ in length with $4 \mathrm{~d}$ between periods (d 1 to 5 ; to remove wethers from metabolism crates). All wethers were kept in a single pen with ad libitum access to hay and water $d 1$ to 5 . On $d 5$, wethers were assigned to a dietary treatment and placed in metabolism crates in a temperature controlled enclosed room for a 10-d adaptation period to metabolism crates and diets, and a 5 -d total collection. Wethers were on a $12 \mathrm{~h}$ light, $12 \mathrm{~h}$ dark schedule.

\subsubsection{Sampling and Laboratory Analysis}

Total mixed ration samples were collected d 15 through d 19 and ort samples were collected d 16 through $\mathrm{d} 20$. Ort and TMR samples were dried in a $60^{\circ} \mathrm{C}$ forced air-drying oven for 48 hours (h) for DM analysis. Total fecal output was collected and weighed on d 16 through d 20 with $7.5 \%$ of the total fecal sample collected, weighed, and placed in a $60^{\circ} \mathrm{C}$ forced-air drying oven for $96 \mathrm{~h}$ for DM analysis. Total urine output was collected on d 16 through $\mathrm{d} 20$. Exactly $100 \mathrm{~mL}$ of $6 \mathrm{~N} \mathrm{HCl}$ was added daily to urinals to maintain urine $\mathrm{pH}<3$. A $25 \%$ subsample of the total urine weight was collected and composited by individual lamb. Total mixed ration, ort, and fecal samples were ground to pass a $1 \mathrm{~mm}$ screen using a Wiley mill (Thomas Scientific, Swedesboro, NJ). Ort samples were composited by lamb within period and TMR samples were composited by period. Feed, ort, and fecal samples were analyzed for NDF (AOAC, 2005) and ADF (AOAC, 2005) by using an Ankom 2000 Fiber Analyzer (Ankom Co., Fairport, NY). Alpha-amylase and sodium sulfite were used in the NDF procedure. Nitrogen concentrations were also measured (AOAC, 2010).

Blood samples were collected on d 15 through d 19, 4 hours post-prandially via jugular venipuncture into $16 \times 100 \mathrm{~mm}$ blood collection tubes (no. 367988; BD Vacutainer, Franklin Lakes, NJ) and refrigerated at $4^{\circ} \mathrm{C}$ for $4 \mathrm{~h}$. Blood samples were centrifuged at $2500 \times \mathrm{g}$ for 20 minutes at $4^{\circ} \mathrm{C}$. Serum was collected into 5 -mL polypropylene tubes. Samples were then stored at $-20^{\circ} \mathrm{C}$ until analysis. Serum urea nitrogen (SUN) concentrations were determined by using a commercial colorimetric kit (Teco Diagnostics, Anaheim, CA) with intra- and interassay CV less than $12 \%$. 


\section{Ml Macrothink}

Table 2. Ingredient and nutritional composition of diets fed to growing wethers (DM basis)

\begin{tabular}{lrrrc}
\hline & \multicolumn{4}{c}{ Dietary Treatment ${ }^{1}$} \\
\cline { 2 - 5 } Item & $0 \mathrm{SB}$ & $15 \mathrm{SB}$ & $30 \mathrm{SB}$ & $45 \mathrm{SB}$ \\
\hline Ingredient, \% & & & & \\
$\quad$ Sugar beets & & 15.00 & 30.00 & 45.00 \\
MSU barley & 45.00 & 30.00 & 15.00 & - \\
Grass hay & 46.00 & 41.00 & 36.90 & 32.80 \\
Soybean meal & 5.50 & 10.40 & 14.80 & 19.00 \\
NaCl & 0.25 & 0.25 & 0.25 & 0.25 \\
Decoquinate & 1.35 & 1.35 & 1.35 & 1.35 \\
Calcium carbonate & 1.00 & 1.10 & 0.85 & 0.75 \\
Mineral premix ${ }^{3}$ & 0.90 & 0.90 & 0.90 & 0.90 \\
Nutritional Composition & & & & \\
DM, \% & 28.33 & 24.97 & 22.59 & 20.72 \\
TDN, \% & 66.80 & 65.80 & 64.80 & 63.60 \\
CP, \% & 15.80 & 15.70 & 15.40 & 15.10 \\
NDF, \% & 44.63 & 41.63 & 37.55 & 38.39 \\
ADF, \% & 28.47 & 27.32 & 22.50 & 23.69 \\
Ca:P & 2.30 & 2.50 & 2.40 & 2.47 \\
\hline
\end{tabular}

${ }^{1}$ Dietary treatments were: 0SB: control diet with no added sugar beets; 15SB: $15 \%$ sugar beets substituted for barley; 30SB: 30\% sugar beets substituted for barley; and 45SB: $45 \%$ sugar beets substituted for barley on a DM basis.

${ }^{2}$ Sugar beets were coarse ground with a flail chopper designed for woody biomass, to reduce choking hazard.

${ }^{3}$ Mineral premix: $13.6 \% \mathrm{Ca}, 10 \% \mathrm{P}, 15.6 \% \mathrm{NaCl}, 1.0 \% \mathrm{Mg}, 0.1 \% \mathrm{~K}$, 2,500 mg/kg Cu, $35 \mathrm{mg} / \mathrm{kg} \mathrm{Se}, 8,500 \mathrm{mg} / \mathrm{kg} \mathrm{Zn,} \mathrm{440,529} \mathrm{IU/kg} \mathrm{vitamin}$ A, 44,053 IU/kg vitamin D, and $881 \mathrm{IU} / \mathrm{kg}$ vitamin E.

Rumen fluid was extracted from all sheep via oral lavage on d 19 of each period at 0700 (pre-prandial) and at approximately 1300 (post-prandial). Rumen fluid $\mathrm{pH}$ measurements were taken immediately after extraction, then samples were stored at $-20^{\circ} \mathrm{C}$. Rumen fluid samples were analyzed for ammonia (NH3-N) concentrations using methods similar to those described by Sigma Technical Bulletin \#640, Chaney \& Marback (1962), Horn \& Squire (1967), and Weichselbaum et al., (1969). Rumen fluid samples were also analyzed for individual volatile fatty acid (VFA) concentrations using a gas chromatography procedure similar to that described by Baumgardt (1964), Supleco Inc. bulletin 749E (1975), Byers (1979), and Fritz \& Schenk (1979).

\subsubsection{Statistical Analysis}

Data were analyzed as a replicated Latin Square, with lamb serving as the experimental unit. Nutrient metabolism data were analyzed using the MIXED procedure of SAS (SAS 9.4; SAS Inst. Inc., Cary, NC). The model included the fixed effects of dietary treatment, period, and 
replicate. The period and dietary treatment interaction as well as the replicate and treatment interaction served as random effects. Day served as the repeated measure used to analyze daily DMI and SUN concentrations using the variance components covariance structure, selected due to the lowest Akaike's information criteria. Fixed effects for SUN and daily DMI were dietary treatment, day, and the interaction. Rumen fluid analysis was conducted with the fixed effects of dietary treatment, time of collection, and the interaction. Time of collection served as the repeated measure with the variance component covariance structure. Linear, quadratic, and cubic orthogonal contrasts of sugar beet inclusion rate served to partition dietary treatment effects. Significance was set at $P \leq 0.05$, with tendencies set at $P \leq 0.10$.

\section{Results}

\subsection{Backgrounding Trial}

Average daily DMI demonstrated a quadratic tendency $(\mathrm{P}=0.06$; Table 3$)$ where $15 \mathrm{SB}$ resulted in the greatest daily DMI, and OSB resulted in the lowest daily DMI. Mid-point BW, final BW, and average daily gain (ADG) were not affected $(P \geq 0.16)$ by dietary treatments. Feed efficiency was not affected $(P \geq 0.12)$ by treatment in the current study.

Table 3. Effects of increasing sugar beets on backgrounding performance of steer calves

\begin{tabular}{|c|c|c|c|c|c|c|c|c|}
\hline \multirow[b]{2}{*}{ Item } & \multicolumn{4}{|c|}{ Dietary Treatment $^{1}$} & \multirow[b]{2}{*}{ SEM } & \multicolumn{3}{|c|}{ Contrasts $^{2}$} \\
\hline & OSB & 15SB & $30 \mathrm{SB}$ & $45 \mathrm{SB}$ & & Linear & Quadratic & Cubic \\
\hline \multicolumn{9}{|l|}{$\mathrm{BW}, \mathrm{kg}$} \\
\hline d 1 & 259.8 & 261.6 & 260.3 & 261.1 & 7.08 & 0.94 & 0.95 & 0.87 \\
\hline d 28 & 299.7 & 302.9 & 302.8 & 304.9 & 8.52 & 0.68 & 0.95 & 0.88 \\
\hline d 50 & 324.0 & 334.8 & 339.3 & 341.7 & 10.54 & 0.27 & 0.67 & 0.92 \\
\hline $\mathrm{ADG}, \mathrm{kg} / \mathrm{d}$ & 1.38 & 1.44 & 1.55 & 1.58 & 0.12 & 0.16 & 0.90 & 0.78 \\
\hline DMI, $\mathrm{kg} / \mathrm{d}$ & 7.14 & 7.70 & 7.60 & 7.25 & 0.28 & 0.80 & 0.06 & 0.69 \\
\hline $\mathrm{G}: \mathrm{F}$ & 0.189 & 0.182 & 0.200 & 0.218 & 0.0159 & 0.12 & 0.41 & 0.71 \\
\hline
\end{tabular}

${ }^{1}$ Diets will be formulated to meet or exceed nutrient requirements of a $295-\mathrm{kg}$ steer gaining $0.91 \mathrm{~kg} / \mathrm{d}$ (NRC, 1996). Treatments were 0SB: 45\% barley and 45\% chopped hay; 15SB: 15\% sugar beets substituted for barley on a \% DM basis; 30SB: 30\% sugar beets substituted for barley; and 45SB: 45\% sugar beets substituted for barley

${ }^{2} \mathrm{n}=12$

${ }^{3} P$-value for the $F$-test of the mean.

${ }^{4} P$-value for linear, quadratic, and cubic effects of increasing sugar beets in the diet.

\subsection{Metabolism Trial}

\subsubsection{Digestibility and N Balance}

The nutrient metabolism results are reported in Table 4. Daily DMI and DM digestibility were not affected $(P \geq 0.25)$ by treatment. There was no treatment effect $(P \geq 0.33)$ on NDF digestibility. However, ADF digestibility demonstrated a tendency to be affected quadratically $(P=0.10)$ by treatment with $15 \mathrm{SB}$ and 30SB producing the lesser values, and OSB and 45SB producing the greater values. Intake of ADF demonstrated a quadratic 
tendency $(P=0.09)$ and demonstrated a pattern that was very similar to what was observed with ADF digestibility. There was no effect $(P \geq 0.18)$ on the excretion of nitrogen through the feces or urine, and no effect $(P \geq 0.22)$ on serum urea nitrogen. Nitrogen balance demonstrated a cubic treatment effect $(P=0.04)$, with 30SB having the highest nitrogen balance and 15SB having the lowest.

\subsubsection{Rumen Characteristics}

Rumen characteristics are reported in Table 5. There was a linear tendency $(P=0.07)$ for rumen NH3-N concentrations to increase as sugar beets increased in the diet. As a result of increasing concentrations of sugar beets in the dietary treatments in the current study, we observed a linear tendency for rumen concentrations of acetate to increase $(P=0.09)$, a linear decrease $(P=0.05)$ in propionate, a linear increase $(P=0.03)$ in the acetate to propionate ratio, and a linear increase $(P=0.01)$ in butyrate that occurred post-prandially. Dietary treatment did not affect concentrations of valerate, isobutyrate, or isovalerate $(P \geq 0.25)$. Rumen $\mathrm{pH}$ at $0700 \mathrm{~h}$ was not affected $(P \geq 0.39)$ by treatment. However, dietary treatment imposed a quadratic effect on $\mathrm{pH}$ at 1300 as sugar beets increased $(P=0.05)$ in the diet. Measurements of $\mathrm{pH}$ at $1300 \mathrm{~h}$ were greatest for $15 \mathrm{SB}$ and was least for $45 \mathrm{SB}$.

\section{Discussion}

\subsection{Backgrounding trial}

The increase in daily DMI between 0 SB and 15SB could be attributable to dietary moisture content. As moisture content increases in the diet, passage rate of the feed through the digestive tract may increase, thus hindering the digestibility of that feed (Trenkle, 1992). Animals will typically increase their intake to make up for the decrease in digestibility (Balch, 1950). This result may also be due to differences in palatability between diets. Nombekela et al. (1994) conducted a study using six multiparous Holstein cows and compared their preferences between sweet, sour, bitter, and salty diets. Four out of six of the cows preferred the sweet diet, and the probability that the cow would choose the sweet diet over the other three diets was 59\%. We also observed that daily DMI started to decrease when more than $15 \%$ sugar beets were included in the diet. This result is similar to results generated by other studies where DMI decreased when wet sugar beet pulp was included in the diet at concentration's greater than 20\% (Olfaz et al., 2005; Lardy and Schafer, 2008). Moisture content has been shown to effect DMI. It has been previously suggested that there may be a threshold of moisture content in the feed where intake starts to decrease due to the added weight of the feed that would lead to the stimulation of stretch receptors in the rumen wall (Voelker and Allen, 2003b). 


\section{Ml Macrothink}

Journal of Agricultural Studies

ISSN 2166-0379

2018, Vol. 6, No. 3

Table 4. Nutrient metabolism characteristics of growing wethers fed increasing concentrations of sugar beets in the diet

\begin{tabular}{|c|c|c|c|c|c|c|c|c|}
\hline \multirow[b]{2}{*}{ Item } & \multicolumn{4}{|c|}{ Dietary Treatment $^{1}$} & \multirow[b]{2}{*}{$\mathrm{SEM}^{2}$} & \multicolumn{3}{|c|}{ Orthogonal Contrasts $^{3}$} \\
\hline & OSB & $15 \mathrm{SB}$ & $30 \mathrm{SB}$ & $45 \mathrm{SB}$ & & Linear & Quadratic & Cubic \\
\hline Initial BW, kg & 36.65 & 36.65 & 36.65 & 36.65 & 0.00 & 1.00 & 1.00 & 1.00 \\
\hline Daily DMI, g/kg BW & 29.12 & 26.01 & 28.03 & 30.43 & 2.51 & 0.61 & 0.30 & 0.68 \\
\hline Daily NDF intake, g/kg BW & 12.48 & 9.57 & 10.50 & 11.14 & 0.85 & 0.41 & 0.04 & 0.27 \\
\hline Daily ADF intake, g/kg BW & 7.80 & 5.96 & 6.88 & 7.13 & 0.60 & 0.68 & 0.09 & 0.20 \\
\hline Daily nitrogen intake, $\mathrm{g} / \mathrm{kg}$ & & & & & & & & \\
\hline BW & 0.68 & 0.63 & 0.90 & 0.74 & 0.07 & 0.10 & 0.33 & 0.02 \\
\hline Total tract digestibility, \% & & & & & & & & \\
\hline DM & 70.34 & 67.23 & 71.29 & 71.4 & 0.20 & 0.44 & 0.44 & 0.25 \\
\hline $\mathrm{NDF}$ & 57.07 & 50.70 & 52.71 & 53.41 & 0.04 & 0.57 & 0.33 & 0.54 \\
\hline $\mathrm{ADF}$ & 51.64 & 40.41 & 48.64 & 50.58 & 0.04 & 0.77 & 0.10 & 0.14 \\
\hline Nitrogen & 74.83 & 72.66 & 74.95 & 72.22 & 1.88 & 0.37 & 0.85 & 0.19 \\
\hline Daily nitrogen excretion, $g$ & & & & & & & & \\
\hline Fecal & 6.57 & 6.16 & 6.37 & 7.51 & 0.70 & 0.36 & 0.29 & 0.92 \\
\hline Urine & 12.23 & 12.31 & 12.03 & 14.41 & 1.02 & 0.18 & 0.27 & 0.51 \\
\hline Serum urea nitrogen, $\mathrm{mg} / \mathrm{dL}$ & 5.65 & 5.03 & 4.39 & 4.87 & 0.53 & 0.22 & 0.31 & 0.63 \\
\hline Nitrogen balance, $\mathrm{g} / \mathrm{kg}$ & 0.16 & 0.13 & 0.28 & 0.14 & 0.05 & 0.63 & 0.24 & 0.04 \\
\hline
\end{tabular}

Although statistically insignificant, there was a numerical increase in ADG as sugar beets increased in the diet. This observation is emphasized in order to show that the inclusion of sugar beets up to $45 \%$ in the diet had no deleterious effects on steer performance, in light of our hypothesis. Arrizon et al. (2012) also generated results indicating that replacing 20 or $40 \%$ of steam-flaked corn with dried shredded sugar beets in total mixed rations for steers on a dry matter basis would have no deleterious effects on ADG. However, Olfaz et al., (2005) observed significant increases in body weight gain when sugar beet pulp was added up to $60 \%$ of grass hay based TMR's for growing male Karayaka sheep. Although we did not observe an increase in $\mathrm{BW}$ or $\mathrm{ADG}$, this may, in part, be due to the increased passage rate due to the increased moisture content of the sugar beet diets. 
Table 5. Ruminal characteristics of growing wethers fed increasing concentrations of sugar beets in the diet

\begin{tabular}{|c|c|c|c|c|c|c|c|c|}
\hline \multirow[b]{2}{*}{ Item } & \multicolumn{4}{|c|}{ Dietary Treatment $^{1}$} & \multirow[b]{2}{*}{ SEM } & \multicolumn{3}{|c|}{ Orthogonal Contrasts $^{3}$} \\
\hline & OSB & $15 \mathrm{SB}$ & $30 \mathrm{SB}$ & $45 \mathrm{SB}$ & & Linear & Quadratic & Cubic \\
\hline Ammonia, mg/dL ${ }^{4}$ & & & & & 2.81 & 0.07 & 0.14 & 0.27 \\
\hline $0700^{6}$ & 22.61 & 22.27 & 24.86 & 26.37 & & & & \\
\hline $1300^{7}$ & 27.19 & 20.80 & 27.49 & 31.35 & & & & \\
\hline \multicolumn{9}{|l|}{ VFA, mol/100 $\mathrm{mol}^{4}$} \\
\hline Acetate & & & & & 3.12 & 0.09 & 0.60 & 0.89 \\
\hline 0700 & 79.68 & 81.00 & 83.35 & 85.13 & & & & \\
\hline 1300 & 76.90 & 81.38 & 83.71 & 82.54 & & & & \\
\hline Propionate & & & & & 3.16 & 0.05 & 0.90 & 0.85 \\
\hline 0700 & 23.93 & 23.65 & 20.55 & 20.03 & & & & \\
\hline 1300 & 29.73 & 25.22 & 21.82 & 18.87 & & & & \\
\hline Butyrate & & & & & 2.20 & 0.62 & 0.67 & 0.80 \\
\hline 0700 & 15.03 & 13.21 & 13.49 & 11.13 & & & & \\
\hline 1300 & 15.33 & 15.49 & 17.37 & 21.39 & & & & \\
\hline Valerate & & & & & 0.24 & 0.26 & 0.63 & 0.51 \\
\hline 0700 & 1.48 & 1.18 & 1.50 & 1.40 & & & & \\
\hline 1300 & 1.54 & 1.27 & 1.09 & 0.97 & & & & \\
\hline Isobutyrate & & & & & 3.00 & 0.39 & 0.95 & 0.45 \\
\hline 0700 & 2.17 & 2.66 & 2.63 & 3.00 & & & & \\
\hline 1300 & 0.75 & 0.75 & 0.50 & 0.56 & & & & \\
\hline Isovalerate & & & & & 3.82 & 0.25 & 0.85 & 0.52 \\
\hline 0700 & 2.72 & 3.31 & 3.48 & 3.83 & & & & \\
\hline 1300 & 0.75 & 0.89 & 0.52 & 0.68 & & & & \\
\hline $\mathrm{A}: \mathrm{P}$ ratio $^{5}$ & & & & & 0.64 & 0.03 & 0.90 & 0.92 \\
\hline 0700 & 3.74 & 4.17 & 4.43 & 4.66 & & & & \\
\hline 1300 & 2.83 & 3.52 & 4.27 & 5.42 & & & & \\
\hline $\mathrm{pH}^{3}$ & & & & & 0.15 & 0.10 & 0.08 & 0.39 \\
\hline 0700 & 7.45 & 7.59 & 7.32 & 7.29 & & & & \\
\hline 1300 & 6.73 & 6.99 & 6.84 & 6.51 & & & & \\
\hline
\end{tabular}

${ }^{1}$ Dietary treatments were: 0SB: control diet with no added sugar beets; $15 \mathrm{SB}$ : $15 \%$ sugar beets substituted for barley; 30SB: 30\% sugar beets substituted for barley; and 45SB: 45\% sugar beets substituted for barley on a DM basis. ${ }^{2} P$-value for the treatment $\times$ time interaction.

${ }^{3} P$-value for linear, quadratic, and cubic effects of increasing sugar beet concentration in the diet. ${ }^{4}$ Rumen fluid extraction and $\mathrm{pH}$ measurements took place at 0700 and at 1300 on $\mathrm{d} 15$ each period.

${ }^{5} \mathrm{~A}: \mathrm{P}$ ratio = Acetate to propionate ratio.

${ }^{6}$ Pre-prandial.

${ }^{7}$ Post-prandial. 


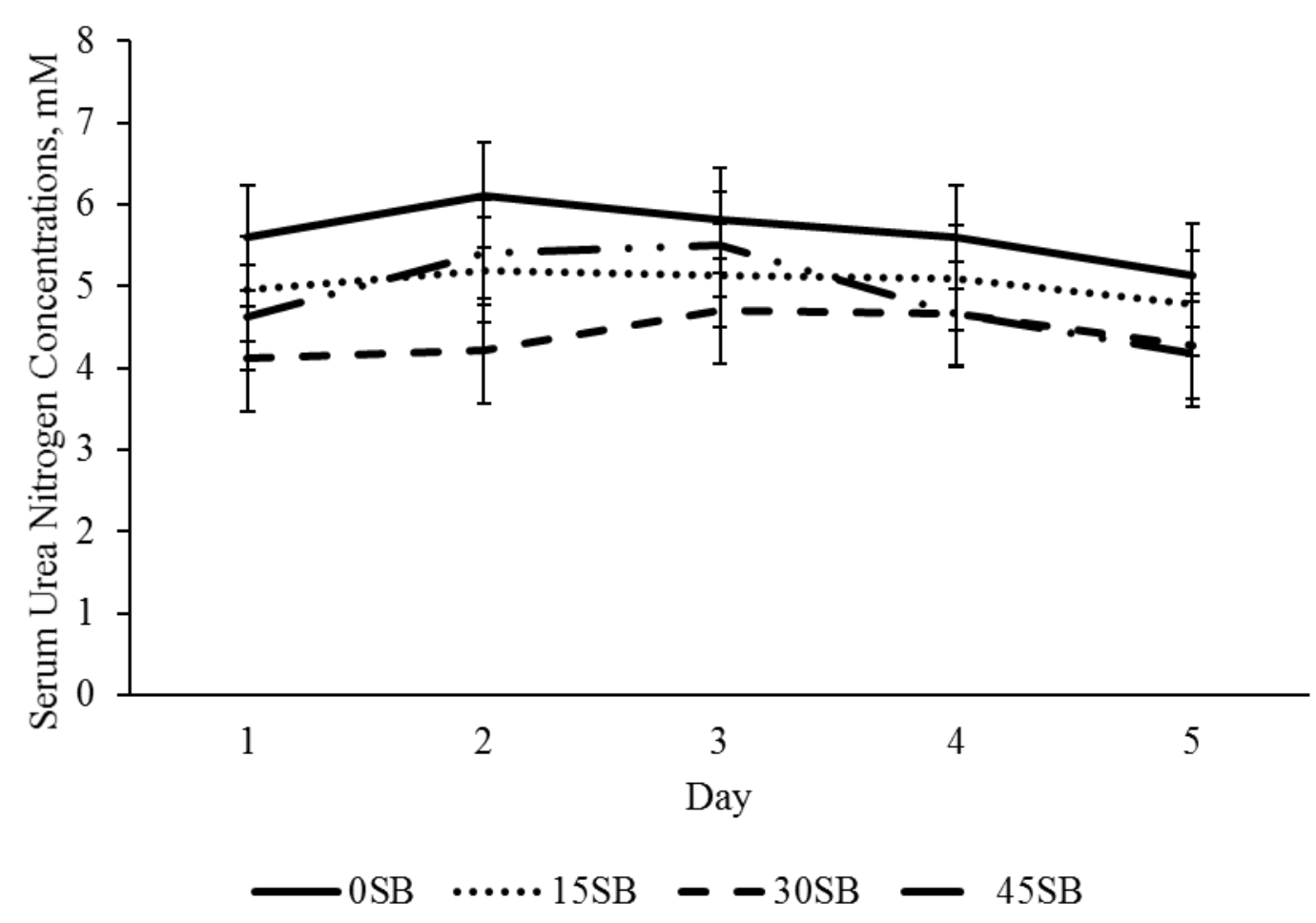

Figure 1. Effects of increasing sugar beet concentrations on wether serum urea nitrogen concentrations. Treatment $\times$ day: $P=0.95$; Day: $P=0.11$; and treatment: $P=0.42$.

Contrary to our results, Arrizon et al. (2012) observed a linear decrease in feed efficiency as dried shredded sugar beets increased in the diet up to $40 \%$ of the dry matter. This could be due to the different protein sources used between the current study and Arrizon et al. (2012). The current study used soybean meal as a protein source, and Arrizon et al. (2012) used alfalfa hay and distillers grains as a protein source. The protein in soybean meal and alfalfa hay is made up of mostly degradable intake protein (DIP; soybean meal 65\% DIP, alfalfa hay mid-bloom 84\% DIP; NRC, 2000), but distiller's grains contain much less DIP (distillers grains + solubles $27.2 \%$ DIP; NRC, 2000). Microbial protein synthesis contributes to a majority of the amino acids that are absorbed in the duodenum of the small intestine, and also contains an amino acid profile that is favorable for meat and milk production (NRC, 2000). Rumen microorganisms require $\mathrm{N}$ for microbial synthesis (Nocek and Russell, 1988). Due to lesser DIP component of distiller's grains as a protein source, it is possible that less $\mathrm{N}$ was available for microbial protein synthesis, thus resulting in a decrease in feed efficiency in the study conducted by Arrizon et al., (2012). This is in contrast to the current study, where soybean meal was utilized as the nitrogen source.

\subsection{Metabolism Trial}

Similar to dry matter digestibility in the current study, Arrizon et al., (2012) did not observe any differences in organic matter digestibility when dried shredded sugar beets replaced steam-flaked corn in TMR's for steers at rates of 0,20 , and $40 \%$ on a DM basis. Contrary to the current study, Huhtanen (1988) observed a decrease in DM digestibility when sugar beet 
pulp replaced barley in a silage-based diet. This may be due to the greater fiber content of the sugar beet pulp diets compared to barley diets used by Huhtanen (1988).

Our results differ from those observed by Arrizon et al., (2012), who reported increased NDF digestibility when dried shredded sugar beets replaced steam flaked corn. The results of the current study also differ from results observed by Huhtanen (1988), who reported increased NDF and ADF digestibility when sugar beet pulp replaced barley in a silage-based diet. This may relate to results generated by Belanche et al (2012), where it was observed that fiber rich diets consistently increased the synthesis of cellulolytic microorganisms when compared to starch rich diets in both high and low protein diets. This relationship is also apparent in results generated by Arrizon et al., (2012) and Huhtanen (1988), where the intakes of NDF and ADF increased as dried shredded sugar beets or sugar beet pulp increased in concentration in the diet, resulting in increased fiber digestibility.

The impacts on nitrogen intake and balance may be partly explained by the increase in soybean meal as sugar beets were added to the diet. The protein in soybean meal is much more soluble in the rumen environment than the protein contained in barley (barley grain $28 \%$ soluble CP; soybean meal $44 \%$ soluble CP; NRC, 2016). Increasing ammonia concentrations indicates an abundance of soluble protein in the diet and in certain instances inefficient use of $\mathrm{N}$ due to bacteria requiring more energy in order to use the excess ammonia for microbial protein synthesis (Nocek \& Russell, 1988), and the possible inefficient use of energy required to excrete urinary nitrogen (Russell, 2002). It's well established that including sugar in a TMR for ruminant animals typically decreases ammonia concentrations (Chamberlain, Thomas, Wilson, Newbold, \& MacDonald, 1985; Huhtanen, 1988; Rooke, Rymer, Maya, \& Armstrong, 1992). Chamberlain et al. (1985) demonstrated that the presence of starch may increase populations of protozoa. Chamberlain et al. (1985), Huhtanen (1988), and Rooke et al. (1992) suggest that increasing protozoa numbers can increase ammonia concentration by the predation of protozoa on the rumen bacteria that would otherwise be utilizing the available ammonia.

As previously discussed, rumen microorganisms require $\mathrm{N}$ to carry out microbial protein synthesis, and energy is required by the microorganisms in order to utilize $\mathrm{N}$ (Nocek and Russell, 1988). It has been suggested that feeding carbohydrates and protein in synchrony can result in improvements in $\mathrm{N}$ utilization and animal performance (Cole and Todd, 2008). Although the diets contained similar amounts of energy and protein, the solubility of the protein source was different as sugar beet concentrations changed in the diet due to the added soybean meal. It seems that available $\mathrm{N}$ may have been lacking in the 15SB treatment, and available $\mathrm{N}$ may have been in excess in the 45SB treatment, as reflected by their respective ammonia levels.

The increase that was observed regarding the acetate to propionate ratio indicates that sugar beets produce an effect that would be characterized as a forage energy source, rather than a concentrate energy source (Lana et al., 1998). These results are consistent with Voelker and Allen (2003a) and Arrizon et al. (2012) where it was observed that concentrations of acetate and butyrate increased, while propionate decreased when pelleted beet pulp or dried shredded 
sugar beets replaced high moisture corn or steam-flaked corn, respectively. Increasing butyrate concentrations may be attributable to the sugar content of sugar beets, as Vallimont et al. (2004) observed a linear increase in butyrate concentrations when sucrose replaced corn starch at rates of $0,2.5,5$, and $7.5 \%$ in TMR's for continuous culture fermenters. Ribeiro et al. (2005) also observed an increase in butyrate concentrations when sucrose supplements were added to alfalfa hay at rates of 0,4 , and $8 \%$. Results from Huhtanen et al. (1988) also observed a tendency for increasing acetate concentrations when sugar beet pulp replaced barley in silage based diets, but observed divergent results as propionate demonstrated a tendency to increase while butyrate significantly decreased when sugar beet pulp replaced barley.

This result is complimentary to those observed by Huhtanen (1988) and Arrizon et al., (2012) where no treatment effect was observed for $\mathrm{pH}$ when sugar beet pulp or dried shredded sugar beets replaced barley or steam flaked corn, respectively. It is important to note that $\mathrm{pH}$ measurements were above 6 amongst all treatments, indicating that microbial synthesis was not limited by pH (Russell and Dombrowski, 1980).

The results from this study demonstrates that sugar beets can replace barley up to $45 \%$ without having any deleterious effects on nutrient metabolism. We also conclude that VFA production patterns can be altered by the addition of sugar beets to total mixed rations for growing wethers.

\section{Conclusion}

Results from the current study support our hypotheses, leading us to make the following conclusions; 1.) Sugar beets fed up to $45 \%$ of the dry matter has no deleterious effects on steer backgrounding performance when compared to barley. 2.) Sugar beets fed up to $45 \%$ of the dry matter has no deleterious effects on the digestibility of fiber or nitrogen when compared to barley. 3.) Sugar beets are capable of altering rumen fermentation patterns when compared to starch-based energy sources. We believe that the results from our sheep metabolism study can be extrapolated to cattle as well, given the similarity between their respective digestive systems and the similar diets between studies. We believe that sugar beets are a safe energy source to be used by livestock producers and can be financially rewarding in some cases. Also, this provides another avenue by which sugar beet producers can sell sugar beets, thus enhancing the financial sustainability of sugar beet growing operations

\section{Acknowledgements}

Funding for these projects was provided by The Bair Ranch Foundation. The authors would like to thank the Western Sugar Cooperative and Dr. Ken Kephart, Southern Agriculture Research Center, for the sugar beets for these trials. The authors would like to thank Cole Ryan, Marley Manoukian, Brady Johnson, Abbey Keyser, and Maria Goettemoeller for their assistance with these projects. 


\section{References}

Agribusiness Handbook. (2009). Sugar beet-white sugar. Food and Agriculture Organization of the United Nations. Rome, Italy.

AOAC. (2005). Official Methods of Analysis ( $18^{\text {th }}$ ed.). Association of Analytical Communities, Arlington, VA.

AOAC. (2010). Official Methods of Analysis (17 $7^{\text {th }}$ ed.). Association of Analytical Communities, Arlington, VA.

Arrizon, A., Carrasco, R., Salinas-Chavira, J., Montano, M., Torrentera, N., \& Zinn, R. A. (2012). Feeding value of dried shredded sugarbeets as a partial replacement for steam-flaked corn in finishing diets for feedlot cattle. Journal of Animal Science, 90(6), 1892-1897. https://doi.org/10.2527/jas.2011-4477

Balch, C. C. (1950). Factors affecting the utilization of food by dairy cows. 1. The rate of passage of food through the digestive tract. British Journal of Nutrition, 4(4), 361-388. https://doi.org/10.1079/BJN19500060

Baumgardt, B. R. (1964). Practical observations on the quantitative analysis of free volatile fatty acids (VFA) in aqueous solutions by gas-liquid chromatography. Dept. of Dairy Sci., Univ. of Wis. Bull. 1.

Belanche, A., Doreau, M., Edwards, J. E., Moorby, J. M., Pinloche, E., \& Newbold, C. J. (2012). Shifts in the rumen microbiota due to the type of carbohydrate and level of protein ingested by dairy cattle are associated with changes in rumen fermentation. Journal of Nutrition, 142(9), 1684-1692. https://doi.org/10.3945/jn.112.159574

Byers, F. M. (1979). Organic acid analysis in rumen fluid and fermented feeds. O.A.R.D.C.

Chamberlain, D. G., Thomas, P. C., Wilson, W., Newbold, C. J., \& MacDonald, J. C. (1985). The effects of carbohydrate supplements on ruminal concentrations of ammonia in animals given diets of grass silage. The Journal of Agricultural Science, 104(2), 331-340. https://doi.org/10.1017/S0021859600044002

Chaney, A. L., \& Marback, E. P. (1962). Modified reagents for determination of urea and ammonia. Clinical Chemistry, 8(2), 130-132.

Cole, N. A., \& Todd, R. W. (2008). Opportunities to enhance performance and efficiency through nutrient synchrony in concentrate-fed ruminants. Journal of Animal Science, 86(E. Suppl.), E318-E333. https://doi.org/10.3945/jn.112.159574

Fritz, J. S., \& Schenk, G. H. (1979). Quantitative analytical chemistry (4th ed.). Allyn and Bacon, University of Michigan, Ann Arbor, MI, USA. 661 p.

Horn, D. B., \& Squire, C. R. (1967). An improved method for the estimation of ammonia in blood plasma. Clinica Chimica Acta, 17(1), 99-105.

https://doi.org/10.1016/0009-8981(67)90102-7 


\section{Macrothink}

Journal of Agricultural Studies

ISSN 2166-0379

2018, Vol. 6, No. 3

Huhtanen, P. (1988). The effects of barley, unmolassed sugar-beet pulp and molasses supplements on organic matter, nitrogen and fibre digestion in the rumen of cattle given a silage diet. Animal Feed Science and Technology, 20(4), 259-278.

https://doi.org/10.1016/0377-8401(88)90001-6

Lana, R. P., Russel, J. B., \& Van Amburgh, M. E. (1998). The role of pH in regulating ruminal methane and ammonia production. Journal of Animal Science, 76(8), 2190-2196. https://doi.org/10.2527/1998.7682190x

Lardy, G., \& Schafer, R. (2008). Feeding sugar beet byproducts to cattle. NDSU Extension Service. AS-1365.

Nocek, J. E., \& Russell, J. B. (1988). Protein and energy as an integrated system. Relationship of ruminal protein and carbohydrate availability to microbial synthesis and milk production. Journal of Dairy Science, 71(8), 2070-2107.

https://doi.org/10.3168/jds.S0022-0302(88)79782-9

Nombekela, S. W., Murphy, M. R., Gonyou, H. W., \& Marden, J. I. (1994). Dietary preferences in early lactation cows as affected by primary tastes and some common feed flavors. Journal of Dairy Science, 77(8), 2393-2399.

https://doi.org/10.3168/jds.S0022-0302(94)77182-4

NRC. (2000). Nutrient requirements of beef cattle ( $7^{\text {th }}$ rev. ed.). Washington, DC: Natl. Acad. Press.

NRC. (2007). Nutrient requirements of sheep ( $7^{\text {th }}$ ed.) Washington, DC: Natl. Acad. Press.

NRC. (2016). Nutrient requirements of beef cattle ( $8^{\text {th }}$ ed.). Washington, DC: Natl. Acad. Press.

Olfaz, M., Ocak, N., Erener, G., Cam, M. A., \& Garipoglu, A.V. (2005). Growth, carcass and meat characteristics of Karayaka growing rams fed sugar beet pulp, partially substituting for grass hay as forage. Meat Science, 70(1), 7-14. https://doi.org/10.1016/j.meatsci.2004.11.015

Ribeiro, C. V. D. M., Karnati, S. K. R., \& Eastridge, M. L. (2005). Biohydrogenation of fatty acids and digestibility of fresh alfalfa or alfalfa hay plus sucrose in continuous culture. Journal of Dairy Science, 88(11), 4007-4017.

https://doi.org/10.3168/jds.S0022-0302(05)73087-3

Rooke, J. A., Rymer, C., Maya, F. M., \& Armstrong, D. G. (1992). Effect of including barley or molassed sugar beet feed in grass silage diets on their digestion by cattle and sheep. Journal of the Science of Food and Agriculture, 58(4), 475-483. https://doi.org/10.1002/jsfa.2740580404

Russell, J. B. (2002). Rumen microbiology and its role in ruminant nutrition. Ithaca, NY.

Russell, J. B., \& Dombrowski, D. B. (1980). Effect of pH on the efficiency of growth by pure cultures of rumen bacteria in continuous culture. Applied and Environmental Microbiology, 39(3), 604-610. 
Sigma Technical Bulletin \#640. The colorimetric determination of urea nitrogen. Sigma Diagnostics, St. Louis, MO 63178.

Supleco Inc. Bulletin 749E. (1975). GC separation of VFA C2-C5. Bellefonte, PA.

Trenkle, A. (1992). Response of feedlot cattle to addition of moisture as water or liquid byproducts to dry feed. Iowa State Univ. Beef Res. Rep. ASL-R921. p. 111-114.

USDA. (2015a). Montana agricultural statistics. Volume LII. Retrieved from https://www.nass.usda.gov/Statistics_by_State/Montana/Publications/Annual_Statistical_Bull etin/2015/Montana_Annual_Bulletin_2015.pdf. (Accessed 18 March 2016.)

USDA. (2015b). U.S. sugarbeet crops: area planted, acres harvested, yield per acre, and production by state and region. Retrieved from http://www.ers.usda.gov/datafiles/Sugar_and_Sweeteners_Yearbook_Table/US_Sugar_Suppl y_and_Use/TABLE14.XLS. (Accessed 18 March 2016.)

Vallimont, J. E., Bargo, F., Cassidy, T. W., Luchini, N. D., Broderick, G. A., \& Varga, G. A. (2004). Effects of replacing dietary starch with sucrose on ruminal fermentation and nitrogen metabolism in continuous culture. Journal of Dairy Science, 87(12), 4221-4229. https://doi.org/10.3168/jds.S0022-0302(04)73567-5

Voelker, J. A., \& Allen, M. S. (2003a). Pelleted beet pulp substituted for high-moisture corn: 3. Effects on ruminal fermentation, $\mathrm{pH}$, and microbial protein efficiency in lactating dairy cows. Journal of Dairy Science, 86(11), 3562-3570.

https://doi.org/10.3168/jds.S0022-0302(03)73961-7

Voelker, J. A., \& Allen, M. S. (2003b). Pelleted beet pulp substituted for high-moisture corn: 1. Effects on feed intake, chewing behavior, and milk production of lactating dairy cows. Journal of Dairy Science, 86(11), 3542-3552.

https://doi.org/10.3168/jds.S0022-0302(03)73959-9

Weichselbaum, T. E., Hagerty, J. C., \& Mark Jr., H. B. (1969). A reaction rate method for ammonia and blood urea nitrogen utilizing a pentacyanonitrosyloferrate catalyzed Berthelot reaction. Analytical Chemistry, 41(6), 848-850. https://doi.org/10.1021/ac60275a046

\section{Copyright Disclaimer}

Copyright for this article is retained by the author(s), with first publication rights granted to the journal.

This is an open-access article distributed under the terms and conditions of the Creative Commons Attribution license (http://creativecommons.org/licenses/by/4.0/). 